\title{
GON, WOO, SEONDO GODDESS, AND CHINESE LEGENDS ABOUT PEOPLE IN KOREAN MYTHOLOGY
}

\author{
Jong-seong PARK \\ Korea National Open University \\ zaotar@naver.com
}

\begin{abstract}
Gon and Woo are mythological persons who were born in China and who performed all their tasks there. That is why they are present in Korean myths from time to time, for instance in the myth about Dangun or the kingdom Goguryeo, and finally they achieve universality and credibility. On the other hand the holy mother Seondo was the daughter of the Chinese emperor who acquired supernatural powers and went to Korea where she stayed. Consequently Koreans did not know much about what she did in China. As a result she became accepted by Koreans as the common goddess of mountains called differently in different regions.

From the point of view of the Korean nation Ju Wonjang and Seol Ingwi are heroes from China but at the same time despite being persons of low birth as commonalty they managed to become heroes. It is an extremely important aspect for Koreans. Although they actually attacked Goguryeo and forced Korea to obey China, for the Korean commonalty such historical experiences could be of different significance. As far as myths about Chinese heroes are concerned, the Korean commonalty seemed to be interested first and foremost in their skills and strength, which were so great that there was no authority in Korea powerful enough to withstand it.

In my opinion for the Korean commonalty the concept of nation was something in the form of an imaginary community, which should arise at any moment by chance and should unify people strongly. The Korean commonality expressed in legends and folktales its strong will to identify themselves with people beyond national divisions in order to save themselves from their hard everyday life. Folktales usually do not present any issue fully. They only present a specific situation or a particular day or something typical of China, etc. By treating Chinese heroes as if they were
\end{abstract}


their own, the Korean commonalty took advantage of them in some sense. I think it was their strategy enabling them to fulfil their dreams by living the life of others.

Key Words: Gon, Woo, Dangun, kingdom Goguryeo, the holy mother, Chinese heroes, nation

\section{곤, 우, 선도여신, 그리고 한국신화 속의 인물들에 관한 중국 전설들}

국문초록: 곤과 우는 중국에서 자신의 출생과 소임을 다한 존재들이다. 그런 까닭에 고유명사로서 우리 신화의 이곳저곳에 사후적으로 연계되면서 단군 신화나 고구려 신화와 보편적 성격을 다져나가는 데에 활용된다. 반면, 성모는 중국 제실의 딸이었다가 신선술을 익혀 우리 땅에 들어와 좌정한 성모여서 중국에서의 특별한 행적을 부각시키지 못했다. 우리 땅에 좌정한 이후 제실의 딸이면서 도래 여신적 존재인 성모로서의 성격은 보통명사화해서 여느 우리 땅의 여산신과도 습융할 수 있는 방식으로 호명되는 운명을 받아들여야 했다고 본다. 이 점이 둘 사이의 차이이고 곤·우와 성모를 달리 수용하는 방식의 차이라고 생각한다.

주원장이나 설인귀나 우리네 민중들의 시선에서는 중국의 영웅이면서 동시에 자신들과 같은 미천한 처지에서 영웅이 된 존재라는 공통점을 갖는다. 그들이 조선에 사대의 예를 강요하거나 고구려를 침탈한 주역이지만 오히려 침탈의 역사적 경험이 민중들에게는 다층적인 함의를 갖게 하는 요인으로 작동했다고 볼 개연성이 있다. 역사적 인물을 매개로 한 중국에 대한 인물전설의 인식은 침탈의 주역으로서 지닌 영웅적 능력, 곧 우리 내부의 어떤 권력도 함부로 제어하지 못하는 그 능력에 초점을 두고 있다.

우리네 민중들에게 민족이라는 인식은 임의적이고 일시적인 상황에서 등장해서 굳건하게 공동체를 결집시키는 상상적 공동체의 성격을 갖는다고 생각한다. 고단한 현실의 문제를 해결하는 방식이 있다면 국적이나 민족을 넘어서서 동일화하려는 몸짓을 설화의 전승을 통해 구현한다. 설화는 일상의 전 영역을 전시간적으로 감당하지 못한다. 특별한 날에 특별한 상황에 특별한 중국의 그 무엇을 사후적으로 되새김질할 뿐이다.

핵심어: 곤. 우. 단군. 고구려. 성모. 중국 영웅들. 민족

1. Introduction

The author is of the opinion that the China, which is present in Korean myths, is depicted as an unreal persona hidden backstage. When one looks into the backstage, however, one discovers a completely unex- 
pected vision of China. China as an object described in myths is real and paradoxical at the same time. In other words it may be said that in Korean myths China is presented as an object, which is relegated to the sidelines by the internal paradoxes. At the same time it has something unreal ingrained in it and that unreal element attacks those paradoxes from its hiding place. It is a paradoxical mechanism existing in myths, which is similar to the liar's paradox.

2. Korean mythology and one of the aspects of mythical references to China

\subsection{Gon and Woo in Goguryeo mythology}

In order to understand how important the Goguryo mythology is for North East Asia and for comprehending China, one needs to focus on the Chinese myths about Gon and Woo. These myths will be analysed. through the prism of Korean mythology Additionally, if one wishes to research into Gon and Woo one must go back to the times of their ancestors that is to say Hwangje (Yellow Emperor), Nakmyeong and Gye (names given in chronological order). However, one needs to limit the investigation as this paper is not devoted to the research into Chinese mythology. ${ }^{5}$

Hwangje, called the Yellow Emperor, is a person officially recognised by the Chinese nation as their God-Progenitor. Gon and Woo were appointed as his descendants and that is why they are extremely important when establishing the genealogy/pedigree of the mythology related to the Han nation. Nakmyeong, born by Hwangje, is a link between Gon and Hwangje because Nakmyeong gives birth to a white horse which becomes Gon. Gon, in turn, is a multidimensional person.

\footnotetext{
${ }^{5} \mathrm{I}$ have already mentioned some of this part in my previous article. See Park JongSeong (2004).
} 
Who are Gon and Woo? Here are a few excerpts about them:

1) The yellow Emperor gave birth to Nakmyeong, Nakmyeong gave birth to the White Horse, and the White Horse became Gon,

2) Once upon a time, he was executed in the Woo Mountains for disobeying the Yellow Emperor but after his death he transformed into the Yellow Bear and immersed himself in the waters of Woo-yeon lake, ${ }^{6}$

3) Gon died in the Woo Mountains, but after his death he transformed into the Yellow Bear and immersed himself in the waters of Woo-yeon lake,

4) the God ordered Chukmyeong to kill Gon in the Woo Mountains but after his death Woo emerged from his belly,

5) They were cutting out his belly with the Odo sword, and Woo arose from it,

6) Woo brought the floods under control and reached the mountain called Hwanwon. There he transformed into a bear. He said to Master Dosan [..] "You may bring me food only when you hear the drum". But Woo stepped on a stone which hit the drum. Master Dosan came and saw him as a bear. The bear ran away thinking that is was a disgrace. When he reached the Sungo mountains, Gye was born. Woo ordered the rock "Give back may son" and the rock opened itself to the north and Gye was born.

It is said that Gon became the Yellow Bear and jumped into the lake called Woo-Yeon. Moreover, Woo also became a bear and became the god of water, which means that he can control waters. So Gon and Woo, the father and the son, are described in a similarly as persons transformed into bears. One cannot say that the superhuman power of controlling waters is strictly connected with bears' powers, but at least people identified both powers in that way.

What seems to be interesting is the fact that Gon, who was killed in the Woo Mountains, became the Yellow Bear and then jumped into the waters of Lake Woo. As he was the god of waters, we intuitively see his strict connection with water. His connection with the lake led to the next mythological event that is to say the birth of his grand-son called Gye.

There are also records saying that after his death Gon became the Yellow Bear and from the fragments cut off from his belly the dragon

\footnotetext{
${ }^{6}$ There is another story about Gon in Classic of Mountains and Seas[山海經]. “Gon's body does not decompose for three years after death. When his body is cut by sword named O[吳刀], Gon is transformed to Yellow Dragon."
} 
arose, and the dragon became Woo (Ryu Dae-Pyeong (劉大平), ed., 2003: 74). However, when it comes to the power of controlling waters, the legends are unanimous claiming that Woo became a bear. Therefore, it should be assumed that Gon and Woo are the gods of waters, they control waters and at the same time are Gods-Bears.

On the other hand, Nakmyeong, who was appointed the father of Gon, is also called Jeonuk. Here is the record attesting it:

There was a fish called the lady Fish who was half-human and half-fish and who was the resurrection of Jeonuk.

Dae-Woo has a body that is half-human and half-fish.

In accordance with these records Jeonuk and his grand-son Woo are both portrayed as half-human and half-fish. It suggests that Jeonuk, Gon and Woo in Chinese mythology belong to one family as a grandfather, father and son. What is more, Gon after his death became the Yellow Bear or the Dragon and jumped into Lake Woo, so Jeonuk, Gonand Woo are persons featured as water gods. Therefore one may claim that the Chinese, when creating the Chinese gods as the gods of five fundamental substances, made Jeonuk the God/Emperor of the North and Hyeonmyong - the god of waters, his assistant/helper.

It may also be assumed that making Gon and Jeonuk direct descendants of the God of Heaven also made them a mixture of the God of Heaven and the God of Waters. However, the record that the Emperor/God of Heaven ordered Chukjung to kill Gon because the latter failed to control the flood suggests that there was a conflict between them, which is to say between the God of Heaven and the God of Waters.

On the one hand, as a result of such relations or conflicts between the God of Heaven and the God of Waters the pedigree of Chinese gods was established in the following manner: the God of Heaven/Emperor - Nakmyeong - Gon - Woo - Gye. On the other hand, due to some unknown reason other gods have been added to the genealogy of Chinese gods.

Gye is the son of Woo, and his mother first had to become a stone to give birth to him. While giving birth she broke into two 
halves, so her son is typified by a mythical element of being "born of stone". It is also said that Gye became the king after his father-founder of the Ha state, but after he acquired the 'nine songs of heaven' he became conceited and started leading a licentious life. Finally, the God of Heaven punished him and his state was annexed to the state of Yugung.

To summarise, Gon and Woo as the descendants of the Emperor (the Emperor is the former God of Heaven who created mankind and Yin-Yang energy so they could breed well) are gods or divine humans having specific features and nicknames such as 'the God of Heaven', 'the White Horse', 'the Dragon', 'the Bear', 'the Woo Lake', 'the Born of Stone'. The genealogy of Chinese mythology (the Emperor the God of Heaven - Nakmyeong - Gon - Woo - Gye) is similarly depicted in the Goguryeo mythological characters (Hwanung Hwanin - Dangun - Haeburu - Geumwa - Jumong). The Emperor / God of Heaven and some of his descendants originate from the Chinese mythology. Thus, it is worth comparing them with the persons appearing in the myths about the foundation of the Goguryeo state (Former Joseon - North Buyeo - East Buyeo - Goguryeo).

The relation between them is as follows:

I generation

Yellow Emperor (God of Heaven) Hwanung (God of Heaven)

II generation

Nakmyeong/Jeonuk (half-man and half-fish/God of Water)

Hwanin (God of Heaven)

III generation

Gon (Bear/Dragon/Woo Lake) Dangun (Bear) Haemosu (God of Heaven/Dragon/The Mountain of the God Bear)

IV generation

Woo (Bear/Dragon) Haeburu Jumong (Dragon)

$\mathrm{V}$ generation

Gye (Born of Stone) Geumwa (Born of Stone/LakeGon)

If similar mythical elements appear just from time to time in single myths and there is no strict connection between them then there is 
no need to investigate similarities between them closely. However if there are similar elements, which seem to be counterparts in myths that have been officially used to provide genealogy then they are worth investigating.

First one must turn one's attention to the fact that Gon became the Yellow Bear after his death, and Woo also became a bear and ruled over water. Additionally, Woo was born out of the belly of Gon. In the Korean myth of Dangun his mother was initially a female bear, and later she became a woman who had a relationship with Hwanung. How did she give birth to him? One may compare Dangun's mother with Gon due to the motive of a bear. People frequently perceive them as separate persons as they assume that Gon is a male God. Is that really true? Analysis of another fragment may reveal more:

In accordance with "Cheonmun" in the chronicle of Chosaor "Woo who was born out of Gon's belly" Gon is not a God but a Goddess. There are also mythical miracles concerning the birth of Woo - 'his mother became pregnant after swallowing the moon from the well', 'Woo was born when the belly of his mother, the daughter of Yusin, was cut out,' etc. - they are typical products of matriarchal society (Jeong Jang 1982). ${ }^{7}$

So if there is a possibility that Gon is a Goddess there are no more problems finding similarities between Gon and Dangun's mother. There is only one difference between them. The mother of Dangun had a relationship with Hwanug/the God of Heaven when she became a woman and stopped being the bear. Gon, in turn, had no relationship at all.

A bear is also the feature of the relationship between Haemosu and Yuhwa:

Before him, Haeburu-the King of the Northern Buyeo already escaped to the Eastern Buyeo. When he died, his son Geumwa succeeded to the throne. One day, at Lake Ubalsuin in the southern part of the Taebaek Mountains Geumwa found a woman and asked her who she was. She told him 'My name is Yuhwa and I am a daughter of Habaeka. When I was playing outside my house with my younger sisters a man told me that he was Haemosu - the son of the God of Heaven. He took me to a house by the River Yalu at the foot of the mountain

\footnotetext{
${ }^{7}$ I quote this part in Seon Jeong-Gyu (1996: 110).
} 
Woongsin (God Bear) and he made love with me. He left and never came back.'

The mountain of the God Bear is the place where Haemosu had a relationship with Yuhwa. If one analyses this example in the narrow sense then the mountain is the Holy Mountain connected with the God Bear. However if one looks at this example in the broader sense remembering that it is the holy place where Jumong- the founder of the state Goguryeo was born, also connected with the God Bear, then one learn that Goguryeo is the successor of Gojoseon, that is to say the former Joseon.

Geumwa and Gye were both born out of the stone. Geumwa went to Lake Gonyeon, and Gon jumped into Lake Woo. Those similar elements remind one of the fact that it is likely that both myths have the same pedigree.

Additionally when Gon became a bear he jumped into Lake Woo-yeon, but the researchers of Chinese mythology interpret the name of the lake in the following manner 'it is a place where the sun sets' ${ }^{8}$ Again, one may find similarities between those two myths. Gon jumped into the lake where the sun sets, and a female bear - the future mother of Dangun entered the cave where there was no light. In other words Gon jumped into the lake when the sun sets and at this moment our hero Woo is born, and a Bear - the future mother of Dangunentered the cave where there was no sun and became a woman. Then she united with Hwanung - the God of Heaven and gave birth to Dangun, the founder of Gojoseon. ${ }^{9}$

\footnotetext{
${ }^{8}$ For more about this, see these two books. Seon Jeong-gyu (1996); Lee In-Taek (2000). In this part, what I have focussed on is a possibility of connection between 'Gon/the lake Woo' and 'Dangun/the cave'. Gon has features of both god of water and god of sun. Gon acquires the position of god of sun after being identified as a descendant of the Yellow Emperor. However, Gon finally jumps into the Woo-yeaon when Gon is transformed into a bear after being killed by the God. It can be interpreted that Gon goes back to the own place where there is no sun. Therefore, the relation between Gon and Woo-yeon is similar with the relation between Dangun and the cave, and it is possible to say there is some significant connection and meaning.

${ }^{9}$ In Korea, a divine feature, which is related to a bear and water is usually concerned with maternal line. On the other hand, in China, because Gon, Woo, and Nakmyeong show a divine feature related to a bear and water, it may be said 'complex' not like in Korea.
} 
Records concerning a direct relationship between Dangun and Woo may be found in another fragment:

Dangun married the daughter of Habaekaand they had a son who was called Buru. Buru was the king of the Easter Buyeo. When the King Woo, called all princes, Dangun sent his son Buru to the meeting. In the eighth year of the reign of Woo in the Chinese state Ha, Dangun and entered the mountain Asadal and became the God of the Mountain.

This fragment may be considered a proof of the fact that a Korean historian Gwongeun was aware, however, not in the historical context, of a certain relationship between Dangun and Haemosu and between Dangun and Woo. Therefore one may claim that Korean mythology with the pedigree (Dangun $\rightarrow$ Buyeo $\rightarrow$ Goguryeo) and Chinese mythology (Yellow Emperor $\rightarrow$ Gon $\rightarrow$ Woo $\rightarrow$ Gye) are strictly connected with each other. ${ }^{10}$

It is a natural thing when one looks at them outside the framework of the Middle Ages universalism. In spite of that one should turn one's attention to the fact that there are specific Chinese elements, which are mixed into the mythology of Goguryeo. In other words how did it happen that Gon and Woo pervaded into the mythological genealogy of Goguryeo, that is to say how Dangun became connected with Woo as well as Geumwa with Gon and Woo.

One may explain it in the following manner: the mythology of an ancient nation is frequently formulated by its original as well as foreign elements. In Korean mythology Gon and Woo do not appear in a chronological order. Simply in a natural automatic way one associates them with each other when reading about the Yellow Emperor and the Woman Bear, mountains of the God Bear, Lake Gonyeon, Geumwa, Dangun and so on. It is possible due to the fact that Gon, Woo, wom-

\footnotetext{
${ }^{10}$ It is enough to be a fundamental discussion how to interpret a phenomenon of homogeny between a myth of Korea and of the Han of China [漢族]. It is easy to say that one is original and the other is derived from an original one, which can occur in a dominance relation or even master-servant relationship. However, since a myth is not only a history of the country (or nationality), but also a religion, philosophy, and literature, one need not make a useless controversy about originality. Abandoning one's own myth and taking another's myth never happened. That can be guaranteed by the example of the Hungarian myth and Jeju Island's myth.
} 
an Bear, Dangun, Geumwa, Gonyeon are all mythical heroes in Eastern Asia.

\subsection{The mythology of Silla and the motive of the holy mother}

The holy mother has a very special place in the myths about Hyeokgeose the founder of the kingdom of Silla and his wife Alyeong. There are numerous holy mothers such as holy mother Seondo, holy mother Seosul, holy mother Dongsin and so on. Therefore researchers have had doubts for a long time whether they were separate figures or just one?

It is certain that the holy mother is connected with Chinese Taoism and that is why her connection with folk beliefs is of special importance. In the opinion of the author of this article, the holy mother after having been received in Korea, in contrast to Gon or Woo, failed to be referred to by her own name and adopted local names thus losing its Chinese features. It means that she was changed into a common goddess who was still called the Great Mother or Holy Mother. The holy mother in Christian culture is perceived in a very similar way. It frequently happens that she is the goddess of folk beliefs or she is simply one of the folk gods.

In Korea the holy mother became a common noun. What does it mean?

Seondo, Seosul or Dongsin function only as personal pronouns, which describe the character of the holy mother. What is interesting is the fact that Kim Busik went to China at the times of the Song dynasty as a king's envoy and paid tribute in the temple Usinto the holy mother Seondo, whom he identified as the holy mother Dongsin, for whom a Chinese official Wangyang previously had written a funeral speech. ${ }^{11}$ Kim Busik who was a historiographer drew such a conclu-

${ }^{11}$ For more information see Kim Jong-Kun (2009: 43-63). 
sion instantaneously. There is a likelihood that he thought that all of the mothers are Taoist figures with one common name.

But the Buddhist monk Ilyeon called the holy mother Seosul holy mother Seondo. It was probably because of the fact that at that time there was a mountain called Seosul, but there was no mountain called Seondo. Thus it seems then the holy mother Seondo was usually understood as the goddess of mountains and the mountain Seondo, which did not exist in fact, was a symbol of the common holy mountain.

There are arguments according to which there were separate cults for the holy mother and for the traditional mountain goddess in the mountains of Jiri. However, it is very difficult to agree with this opinion. From the moment when the holy mother cult (typical of Chinese Taoism) pervaded into Korean culture, she became a common goddess of the mountains. Therefore the holy mother is no longer associated with the holy mother Seondo in Korea. She became a common goddess of mountains there and additionally was featured differently depending on regions where her cult was practiced.

Due to that she also participated in building the kingdom of Buddha in the territory of Silla, and was the Great Mother who gave birth to the son - the great King. As a wife of the God Banyashe was the goddess of weaving. Being the Dragon she gave birth to Alyeong, she also gave birth to the son and the daughter who married and became the founders of the kingdom. ${ }^{12}$ And that way she contributed to the creation of the myth about the marriage between a brother and a daughter. She was also the holy mother who helped Lee Seongye, the founder of the Joseon dynasty, to win a war.

As we can see the holy mother has different features and personalities in Korea; her religious authority of Taoism spreads and pervades Buddhism. She helps her husband gain power by making him wear a court garment which she has sewn herself. In the critical moment of the war she interferes to protect the mother land, and so on. Although Koreans accepted the holy mother who came from China, they changed her. She was no longer a Taoist goddess but a universal goddess helping people in different matters. So the fate of the holy

\footnotetext{
${ }^{12}$ It is interesting to observe that Nüwa and Fuxi are linked by the specific motif, marriage between brother and sister.
} 
mother is completely different to the fate of Gon and Woo, who are accepted in Korean mythology without losing their specific features.

Gon and Woo are mythological persons who were born in China and who performed all their tasks there. That is why they are present in Korean myths from time to time, for instance in the myth about Dangun or the kingdom Goguryeo, and finally they achieve universality and credibility. On the other hand the holy mother was the daughter of the Chinese emperor who acquired supernatural powers and went to Korea where she stayed. Consequently Koreans did not know much about what she did in China. As a result she became accepted by Koreans as the common goddess of mountains named differently in different regions.

\section{Korean legends about Chinese personas - JuWon- jang, Nuruhachi, Han Cheonja, SeolIngwi}

Among the former Chinese emperors the following appear most frequently in Korean folk stories: JuWonjang, Nuruhachi, and Han Cheonja. ${ }^{13}$ We should also mention Lee Semin the first emperor of the Chinese dynasty, who is such an important personage that at the island of Jeju there was a special shaman ceremony to pay homage to him.

In general, anecdotes about their mythical incredible births are passed on orally. It is said that Lee Semin is the son of the unknown father, being an extraordinary persona such as a dragon or a gigantic snake and so on. It is said that his father secretly entered his mother's room in the middle of the night and he inseminated her or that he gained the best place as a result of geomancy and due to that he became an Emperor, etc.

However, the myths mostly focus on their history from the moment of birth till the moment of gaining power. One may find no information about their lives after gaining power. It is probably due to

\footnotetext{
${ }^{13}$ In order to see the oral literary pieces and its meaning of Korean legend about cheonja [天子] see Seo Dae-Seok (2011).
} 
the fact that folktales are not interested in specific events from the history of a given nation. We should, however, turn our attention to the fact that Lee Semin and Nuruhachi being the Emperors of China attacked Goguryeo and Joseon, that is to say Korea. Thus it is very difficult for Koreans to accept them as great heroes. Nevertheless there are legends about them in Korea.

When investigating the anecdote about the birth of Han Cheonja one may draw a conclusion that he could have been either JuWonjang or Nuruhachi. The legend tells of JuWonjang who was born into a poor, common family. He made his way to the Emperor's throne on his own. The Korean commonality probably perceived him as a hero because he was of low birth, as they were, and yet he managed to overcome all difficulties and became an emperor. They could have perceived him also as a man who was chosen by the God of Heaven to become an emperor. The stories about Nuruhachi are completely different as it is said that he was born into the family of a wealthy landowner and he is perceived negatively as a person of great talent who attacked the Korean nation inflicting enormous suffering.

The author is of the opinion that in the world of Korean folktales they were not discriminated against because of their nationality. It should also be stressed that there are not many tales about their births in China.

The story of SeolIngwi does not differ much ${ }^{14}$ In the town of Pa$\mathrm{ju}$ in Korea there is a tale about him. The tale tells that he was born in the Gamak in this region but he could not speak until he reached 15. $\mathrm{He}$ ate a lot and he was incredibly strong etc. In China in turn there are legends only about his extraordinary deeds during wars.

Emotional closeness with and acceptance of China or Chinese historical characters among the Korean nation is a direct result of the Korean historical experiences. What may be interesting is the fact that in accordance with some records Lee Semin, the founder of the Dang dynasty in China, is the progenitor of the Lee family in the region of Jeonjuin Korea. It is hard to prove it because the pedigrees of those two families seem to be different. But it should be remembered that

\footnotetext{
${ }^{14}$ About the Seol Ingwi legend see Lee Ki-Huyng (2006).
} 
tales and legends about Lee Semin are not totally based on historical sources.

If one realises that the government of Korea was the source of suffering of the people who inhabited the island of Jeju, then one may easily understand that even the Chinese ruler Lee Semin could have been considered a great and kind-hearted emperor, whom the people could easily accept. To conclude, it simply could have happened due to the very hard life led by the people of Jeju.

JuWonjang, the founder of the Ming dynasty in China, is connected with Lee Seonggye, the founder of the Joseon dynasty in Korea. According to the legends initially JuWonjang was in a much worse situation than Lee Seonggye. But he cheated him and in accordance with Taoist geomancy gained a better place. That is how he became the Emperor of China. It may also be said that JuWonhang was more ambitious than Lee Seonggye, and that is why he became an Emperor of China whereas Lee Seonggye became the King of Korea. Of course this legend expresses a very simple concept that the Emperor of China is a much greater and more important person than the King of Korea.

But the Korean commonalty had other arguments to support its belief:

1. China was a very big state and Korea was a small one,

2. an Emperor - the representative of Heaven - ruled in China, whereas in Korea the King ruled,

3. there was some emotional closeness to JuWonjang, and distance to Lee Seonggye,

4. life under the reign of Lee Seonggye was hard,

5. the only person who could protect the Korean nation against the unjust, excessively burdening reign of Lee Seonggye and his vassals was JuWonjang due to the fact that he was of low birth but nevertheless he managed to become an emperor.

The superhuman deeds of Lee Semin, the founder of the dynasty Dang in China, were passed on in shaman songs in the island of Jeju, but not in the mainland of Korea. It is an example of the fact that his features and function were changed in Korean folktales.

From the point of view of the Korean nation JuWonjang and SeolIngwi are heroes from China but at the same time despite being 
persons of low birth as the commonality they managed to become heroes. It is an extremely important aspect for Koreans. Although they actually attacked Goguryeo and forced Korea to obey China, for the Korean commonality such historical experiences could be of different significance. As far as myths about Chinese heroes are concerned, the Korean commonality seemed to be interested first and foremost in their skills and strength, which were so great that there was no authority in Korea powerful enough to stand against it.

In my opinion for the Korean commonality the concept of nation was something in the form of imaginary community, which should be resurrected in any moment by chance and should strongly unify people. The Korean commonality expressed in legends and folktales its strong will to identify themselves with people beyond national divisions in order to save themselves from their hard everyday life. Folktales usually do not present any issue fully. They only present a specific situation or a particular day or something typical of China, etc. By treating Chinese heroes as if they were their own, the Korean commonality took advantage of them in some sense. It was probably their strategy enabling them to fulfil their dreams by living the life of others.

\section{Bibliography}

Jang Deok-Sun et al. 2005. 『구비문학개설』(증보판). 서울: 일조각. Jeong Jang, 1982, “鯀禹治水神話的産生和演變,”『民間文學論文 選』, 湖南人民出版社, pp. 51-55.

Kim Jong-Kun. 2009. "Modification pattern of Sundosungmo story and the meaning". A Journal of Onji, No. 32, pp. 43-63. Seoul: The Society of Onji Studies.

Lee In-Taek. 2000. 『중국 신화의 세계』, 서울: 풀 빛.

Lee Ki-Huyng. 2006. "Comparative Research on Seol Inkwi Legends". Journal of Korean folklore, No. 44. Seoul: The Korean Folklore Society.

Park Jong-Seong. 2003. '헝가리의 創世 및 民族起源神話의 再編樣相', 『동유럽연구』12권 1 호. 서울: 한국외국어대학교 


\section{동유럽발칸연구소.}

Park Jong-Seong. 2004. "Why, now, Goguryo mythology". The Journal of Humanities, No.9, pp. 27 56. Seoul: The Institute of Humanities (The Catholic University of Korea), pp. 27-56.

Ryu Dae-Pyeong (劉大平) 編著，『中國神話經典』，內蒙古大學出版社， 2003.

See Kim Jong-Kun, "Modification pattern of Sundosungmo story and the meaning," A Journal of Onji, The Society of Onji Studies, 2009, pp. 4363.

Seo Dae-Seok, 2011. 『이야기의 의미와 해석』. 서울: 세종출판사.

Seon Jeong-Gyu. 1996. 『중국신화연구』, 서울: 고려원. 